Abstracta Iranica Abstracta Iranica

Revue bibliographique pour le domaine irano-aryen

Volume 27 | 2006

Comptes rendus des publications de 2004

"Sister Shi'a States? Safavid Iran and the Deccan in the 16th Century ». Deccan Studies, 2/2 (2004), pp. 44-72.

Rudi Matthee

(2) OpenEdition

Journals

Édition électronique

URL: http://journals.openedition.org/abstractairanica/5992

DOI : 10.4000/abstractairanica.5992

ISSN : 1961-960X

Éditeur :

CNRS (UMR 7528 Mondes iraniens et indiens), Éditions de l'IFRI

Édition imprimée

Date de publication : 15 mai 2006

ISSN : 0240-8910

Référence électronique

Rudi Matthee, " «Sister Shi'a States? Safavid Iran and the Deccan in the 16th Century ». Deccan Studies, 2/2 (2004), pp. 44-72. », Abstracta Iranica [En ligne], Volume 27 | 2006, document 188, mis en ligne le 02 janvier 2007, consulté le 25 septembre 2020. URL : http://journals.openedition.org/ abstractairanica/5992 ; DOI : https://doi.org/10.4000/abstractairanica.5992

Ce document a été généré automatiquement le 25 septembre 2020.

Tous droits réservés 


\section{« Sister Shi'a States? Safavid Iran and the Deccan in the 16th Century ». Deccan Studies, 2/2 (2004), pp. 44-72.}

\section{Rudi Matthee}

1 This thoughtful and well documented article revisits the link between Safavid Iran and its "satellite" Shi'i states in the Deccan, Ahmadnagar (the Nizamshahi kingdom), Golconda (Hyderabad, the Qutbshahi kingdom), and Bijapur (the 'Adilshahi dynasty), a topic on which little has been written since M. A. Nayeem and H. K. Sarkar dealt with it three decades ago. The author contests the traditional view, according to which the emergence of these states in the 16th century and their adoption of Twelver-Shi'ism were a function to the prior influx of Iranians from Safavid Iran into India bringing an orthodox form of Twelver-Shi' ism with them, on the grounds that formal Shi'im was still a long way off in the early Safavid polity. Instead, he makes a strong case for a much more heterodox set of influences, with a strong element of Sufism permeating an amalgamation of Sunni and Shi' $\mathrm{i}$ beliefs among the founders of these various dynasties.

\section{INDEX}

Thèmes : 4.2.1. Safavides et Qâjârs

nompropre Safavides 
AUTEURS

RUDI MATTHEE

University of Delaware 